\title{
EDITORIAL
}

\section{Nuclear impressionism: how the active genome creates the very canvas on which gene expression is painted}

\author{
Thoru Pederson \\ Department of Biochemistry and Molecular Pharmacology and Program in Cell Dynamics, University of \\ Massachusetts Medical School, Worcester, USA
}

\section{DEDICATION}

This paper is presented in honor of Karel Smetana, who has taught us so much about the nucleus - always accompanied by his grand, engaging smile.

\begin{abstract}
Summary
This paper concerns the functional architecture of the cell nucleus. Though it is DNA that carries our literal blueprint, our ancestry includes the nucleus itself, passed down through the 2.5 billion year evolutionary history of the Eukarya. Nuclear structure is presented here as two contrasting possibilities. In one case, the nucleus is envisioned as being built upon a backbone of protein filaments, analogous to the cytoskeleton. In this conceptual framework, the chromosomes are considered to passively adopt locations that are dictated by their attachments to the imagined skeleton, and their activity is postulated to be the result of such attachments. In the other case, nothing in the architectural design of the nucleus is more deterministic than the chromosomes themselves, and their activity. Here, gene activity is thought to be based on the binding of DNA sequence-specific activator or silencing proteins that arrive at their target sites by diffusion. Moreover, additional elements of nuclear structure are viewed as arising from the very action of the genes themselves, such as nascent mRNAs packaged into ribonucleoprotein particles as well as large, heterotypic molecular machines involved in RNA processing. In this case, termed the "genome-centric model", the observed structure of the nucleus is not based on some underlying, prefabricated skeleton, but is in fact the actual ongoing cytological manifestation of genes in action. Upon careful analysis of all the evidence, the genome-centric model enjoys favor at the present time. However, we are still in kindergarten days in our understanding of the cell nucleus and, as always, it is wise to keep an open mind. New advances in biophysical, nanotechnology and systems biology approaches to nuclear architecture encourage us to believe that we may soon graduate into the gymnasium - if not university, level of our nuclear education. Viewed metaphorically as art (as in the playful title of this paper), we understand the paint at every atom of pigment on the palette i.e., the covalent genome, the DNA. It is the final, creative work as applied to the gene expression canvas itself that we must now strive to know.
\end{abstract}

Keywords: Genome - nucleus - chromosomes - gene expression 
"We shall not cease from exploration And the end of all our exploring Will be to arrive where we started And know the place for the first time."

T.S. Eliot

\section{IS THIS IMPORTANT?}

Two contrasting conceptual ideas about the structure of the cell nucleus are put forth in the Summary. Beyond the goal of knowing the truth (which should always be sufficient in our profession), is there any practical reason to care which of the two general models is the case?

Yes, I think. If the nucleus has a deterministic underlying backbone other than the genome itself, we will surely need to know it in order to attack diseases or disorders that arise from errors in this imagined nuclear skeleton. Just at the time this paper is being written, there is excitement because a point mutation in the gene for one of the nuclear lamina proteins has been linked to the human premature aging disease progeria. The nuclear lamina is not a questioned nuclear structure (and does not extend into the nuclear interior as a scaffold-like structure.) Yet the fact that a single point mutation in a genome-enveloping protein can precipitate a premature aging disease is most intriguing.

On the other hand, if the nucleus is designed, causatively, by the action of genes themselves, such actions reflecting simple bimolecular collisiondependent reactions of the genome with various DNA sequence-specific binding proteins, then the battle line for understanding human diseases related to gene expression must be drawn at the primary DNA sequence level itself, an enterprise that of course is now underway with great intensity in both academic and industrial laboratories (e.g. haplotyping). For me personally, the basic curiosity motive is more than sufficient, but we should of course hold out the hope that the context of this work might someday productively reach the patient.

\section{THE NUCLEAR SCAFFOLD CONCEPT}

The objections to this idea are based on the lack of any compelling ultrastructural evidence for a nuclear matrix running through the inter-chromatin space (Pederson 1998, 2000a). Moreover, the apparent ease with which large molecular complexes move in the inter-chromatin space also argues against any infrastructure possessing a crosssectional mass density that impedes diffusion (Politz et al. 1998, 1999, Daneholt 1999, Pederson 2000b, Politz and Pederson 2000, Pederson 2001). Even very large nuclear particles, such as Cajal bodies and PML bodies, move through the inter-chromatin space by a process that appears to be mainly diffusion-based (Pederson 2002). There are two reports of proteins that appear, at the light microscope level, to extend throughout the nucleus (Oegema et al. 1997, Wasser and Chia 2000) but in neither of these studies were the distributions examined at the ultrastructural level. An additional consideration is the accumulating evidence for the presence of actin, actin-related proteins and myosin in the nucleus (Pederson and Aebi 2002). While the oligomer/polymer status of actin in the nucleus is unknown at present, its presence in the nucleus warrants attention.

\section{THE GENOME-CENTRIC MODEL}

The genome-centric model was articulated in a recent article (Pederson 2002) but has much earlier intellectual origins (as do most so-called "new" ideas). When the "lampbrush" chromosomes of amphibian oocytes (Callan and Lloyd 1960) are gently teased out of their nuclear residence, the germinal vesicle, these chromosomes display no evidence of any tethering infrastructure. Moreover, the various classes of small intranuclear particles, such as mRNA splicing factor-containing bodies ("snurposomes") and Cajal bodies, are observed to float freely about in the opened nuclear contents (Gall 1998). A similar freedom and dispersion of chromosomes is seen when the polytene nuclei of a dipteran insect's larval salivary glands are gently opened with watchmaker's forceps (Sass and Pederson 1984). Both of these biological situations, amphibian oogenesis and insect larval development, are ones of intense gene transcription and mRNA export from the nucleus and yet in neither case is there evidence that the chromosomes are attached to any nuclear framework. 


\section{THE VISITORS OF GENES IN THE DIFFUSIONAL NUCLEUS - THE "NANONUCLEUS"}

It now appears that genes receive regulatory visitors by diffusion and binding, not by any directly vectored axis of delivery (Pederson 2000b, 2001, Becker et al. 2002). Other nuclear bodies, larger than transcription factors themselves, also visit the chromosomes in the diffusional world of the nucleus (Pederson 2002). There is an emerging sense that many sentinels roam throughout the genome, not moving along structured tracks but by the process embodied in the second law of thermodynamics, the search for randomness called diffusion.

A new and exciting area of research that is developing seeks to combine biophysics and nanotechnology to the study of the cell nucleus (Politz and Pombo 2002, O'Brien et al. 2003). In parallel, various groups are beginning to approach the nucleus from the standpoint of systems biology (e.g. Davidson et al. 2003). Eventually, it may be possible to determine actual values for parameters such as the molar activities of various nuclear molecules, the water content of the nucleoplasm (and thus the true concentrations of solutes) and its fluid viscosity. Such progress will not only enable us to view the nucleus as chemical biology, but should- at last, move us toward resolution of the perennial question of whether the nucleus has a functionally relevant, non-chromatin infrastructure, or is simply the physical manifestation of the active genes.

\section{ACKNOWELEDGEMENTS}

Work from the author's laboratory is funded by grants from the U.S. National Institute of General Medical Sciences, and a grant from the Human Frontier Scientific Program Organization.

The many scientific contributions of Joan Politz in the author's laboratory are also warmly acknowledged.

Received 30 $0^{\text {th }}$ May 2003.

Published online $27^{\text {th }}$ June 2003.

Simultaneously published in J. Berger (ed): Advances in Cell Biology. Kopp Publ., České Budějovice 2003, p.1-8.

\section{REFERENCES}

Becker M., C. Baumann, S. John, D.A. Walker, M. Vigneron, J.G. McNally, G.L. Hager: Dynamic behavior of transcription factors on a natural promoter in living cells. EMBO Rep. 3: 1188-1194, 2002.

Callan H.G. and L. Lloyd: Lambrush chromosomes of crested newts Triturus cristatus (Laurentii). Phil. Trans. Roy. Soc. Lond., Ser. B, 243: 135219, 1960.

Daneholt B.: Pre-mRNP particles: from gene to nuclear pore. Curr. Biol. 9: R412-R415, 1999.

Davidson E.H., D.R. McClay, L. Hood: Regulatory gene networks and the properties of the developmental process. Proc. Natl. Acad. Sci. USA 100: 1475-1480, 2003.

Gall J.G.: Spread preparations of Xenopus germinal vesicle contents. In D.L. Spector, R.D. Goldman, L.A. Leinwand (eds.): Cells: A Laboratory Manual, Cold Spring Harbor Laboratory Press, Plainview NY, 52.51-52.54, 1998.

O'Brien T.P., C.J. Bult, C. Cremer, M. Grunze, B.B. Knowles, J. Langowski, J. McNally, T. Pederson, J.C. Politz, A. Pombo, G. Schmahl, J. Spatz, R. von Driel: Genome function and nuclear architecture: from gene expression to nanoscience. Genome Res. 13: 1029-1041, 2003.

Oegema, K., W.F. Marshall, J.W. Sedat, and B.M. Alberts: Two proteins that cycle asynchronously between centrosomes and nuclear structures: Drosophila CP60 and CP190. J. Cell Sci. 110: 1573-1583, 1997.

Pederson T.: Thinking about a nuclear matrix. J. Mol. Biol. 277: 147-159, 1998.

Pederson T.: Half a century of the nuclear matrix. Mol. Biol. Cell 11:799-805, 2000a.

Pederson T.: Diffusional transport within the nucleus: a message in the medium. Nat. Cell Biol. 2: E73-E74, 2000b.

Pederson T.: Protein mobility within the nucleuswhat are the right moves? Cell 104: 635-638, 2001.

Pederson T.: Dynamics and genome-centricity of interchromatin domains in the nucleus. Nat. Cell Biol. 4: E287-E291, 2002.

Pederson T. and U. Aebi: Actin in the nucleus: what form and what for? J. Struct. Biol. 140: 3-9, 2002.

Politz J.C., E.S. Browne, D.E. Wolf, T. Pederson: Intranuclear diffusion and hybridization state of oligonucleotides measured by fluorescence correlation spectroscopy in living cells. Proc. Natl. Acad. Sci. USA 95: 6043-6048, 1998. 
Politz, J.C., R.A. Tuft, T. Pederson, R.H. Singer: Movement of nuclear poly(A) RNA throughout the interchromatin space in living cells. Curr. Biol. 9: 285-291, 1999.

Politz, J.C. and T. Pederson: Movement of mRNA from transcription site to nuclear pores. J. Struct. Biol. 129: 252-257, 2000.

Politz, J.C. and A. Pombo: Genomics meets nanoscience: probing the genes and the cell nucleus at $10^{-9}$ meters. Genome Biol. 3: reports4007.1-reports4007.3, 2002.
Sass, H. and T. Pederson: Transcription-dependent localization of U1 and U2 small nuclear ribonucleoproteins at major sites of gene activity in polytene chromosomes. J. Mol. Biol. 180: 911-926, 1984.

Wasser, M. and W. Chia: The EAST protein of Drosophila controls an expandable nuclear endoskeleton. Nat. Cell Biol. 2: 268-275, 2000.

\section{* Address:}

Thoru Pederson, Department of Biochemistry and Molecular Pharmacology and Program in Cell Dynamics, University of Massachusetts Medical School, Worcester, Massachusetts 01605, USA; thoru.pederson@umassmed.edu 